\title{
Education for Internationalism with Respect to Globalization, Modernization, and Multiculturalism
}

\author{
Article by Abdulai Abdul-Malik \\ Public Health, Texila American University, Ghana \\ E-mail:saanbu@yahoo.co.uk
}

\section{Introduction}

There is no agreed construction of an acceptable inclusive definition of term international education. The term therefore is ambiguous as it appears to refer to contrasting usages in educational studies. The terminology most often discussed in the context of the fields that are related to comparative education, but a different sense of the term has also developed in the context of the theory and practice of education in international schools and other institutions (Cambridge* et al., 2004). This write up will therefore explore the different perspectives of the terminology. International education will also be discussed with with respect to globalization, modernization, and multiculturalism. A comparative analysis of education in USA and Japan with respect to the constitutional provision, administration, finance and educational structure will also be discussed.

What do you mean by international education? Describe education for internationalism with respect to globalization, modernization, and multiculturalism

\section{International education}

International education is mostly discussed in the context of comparative education. Recently a different sense of the term has also emerged in the context of the theory and practice of education for 'international-mindedness' in international schools and other institutions. Comparative education develops from a well-positioned theoretical tradition of academic studies and this makes comparisons between national systems, but international education is 'more explicitly applied and action-oriented' (Crossley, 1999, p. 255). International education is therefore placed in the context of international development aid and the transfer of expertise between and among national systems of education. Watson, (1999) also identifies comparative education as a theoretical studies and international education with application and practice, he however, recognizes a distinctive ideology of internationalism that intends developing international attitudes and creating awareness. Lowe (1998, pp. 18-19) also recognises this distinction but in the context of universities that are largely derived from a practical involvement in education in developing countries. The use of the term to international education to describe the work and study of international schools is acknowledged by Crossley and Watson (2003), who recognises the role of international schools in preparing students for "employment anywhere in the world', there is also the component of developing 'an understanding of different countries, as much as developing good relations with people of different nationalities and languages' (p. 14). In internalising education here is need to align the curriculum and assessment of education offered by international schools. It is however not the case at the moment (Hayden \& Thompson, 1995).

One other aspect of the definition is that international education transcends national borders by the exchange of people, for instance, by students travelling to study at an international branch campus, as part of a study abroad program or as part of a student exchange program. The other aspect of the definition describes is a comprehensive approach to education that intentionally prepares students to be active and engaged participants in an interconnected world. It also means allowing students to think with an international or global perspective by connecting them with different societies and belief systems which will enable them to understand and embrace cultural differences and similarities'.

International education also embraces several aspects including, but not mutually exclusive to: international student recruitment, international admissions, student mobility, international compliance and governance, international student administration and student experience, transnational education (TNE), international partnerships, relations and networks, and internationalised curriculum. 
DOI: $10.21522 /$ TIJPH.2013.05.04.Art032

ISSN: $2520-3134$

\section{Education for internationalism with respect to globalization, modernization and multiculturalism}

It is noted that until the field of international education can adequately define the terminologies internationalization and globalization, the value and or significance of their application to the development and implementation of various types of study abroad programs will be limited. Limitations of that nature will further reduces the profession's ability to respond to the curricular and experiential needs of today's students. International education provides learning opportunities and scholarship. It also builds understanding and respect among different peoples; and enriches constructive leadership in the global community. Leach (1969) relates internationalism with the maintenance of relations between different countries, and describes three approaches to its application in the field of education: unilateral internationalism, this about a country concerning itself with the education of its people abroad; bilateral internationalism, which involves students of two different countries exchanging information mostly at university level; and multilateral internationalism, requiring funding from at least three national sources, with none of them dominating (Altbach and Knight, 2007). Internationalization is often confused with globalization. Globalization is defined as the economic, political, and societal forces pushing $21 \mathrm{st}$ century higher education toward greater international involvement. The results of globalization include the integration of research, movement of labour, the adoption of English as the language for scientific communication, the growing international labour market for scholars and scientists, the growth of communications firms and of multinational and technology publishing, and the use of information technology (IT) (Altbach and Knight, 2007).

Regardless of how they are defined, globalization and internationalization is expected to take on increased significance in the next millennium; this is resulting from technology, communications, and transportation serving as the mechanisms for potential social, political, and/or economic collisions between people of the world. Given the convergence of modernization between countries, educators must consider the ramifications of such a pattern in terms of how to best prepare students for the processes of both globalization and internationalization(Mccabe, 2001).

International education when placed in a global context must takes into account 'economic, political, and cultural-ideological transnational practices' (Sklair, 1991). From this perspective, it is evident that the practice of international education will be shaped by the transnational practices that are identified with the processes of globalization. International education is part of the process of economic globalization. International schools are a free market response to a global need (Pearce, 1994). Not only is international education influenced by globalization but it also facilitates the spread of free market values. Indeed, the presence in a country of a school offering international education may introduce competition with the national educational system (Cambridge et al., 2010). Thus, the ideological underpinning of international education as currently practised constitutes the reconciliation of a dilemma between the contrary trends of cooperation through international relations and competition through economic globalization.

The idea of modernization explains how societal development essentially goes through a series of stages, coupled with technological base of production in each phase. Modernization, should be viewed as a potential means to close the gap among nations. Modernization is the evolution and development of technology in a society (Azeutziu, 2014). Modernisation theory was prominent in 1970s with premise that development is conditional upon members of a society holding modern values. Critiques of modernisation accuses modernisation of using the current dominant values in western societies as model for traditional societies adopt (Phillips and Schweisfurth, 2014

Modernization encompasses change in socio-economic, educational and political systems extending from the societies of Western societies. It is a social change that involves the elements of science and technology and their far-reaching effects on social values, social behaviour and practices. The use of education to spread the values of modernisation started gaining prominence between 1960s and 1970s onward. The scientific and technological ideas needed to be transferred and shared. An extensive change involving social, economic, and political system can only be done through education. Education therefore, has become an influence instrument in this change. (Aggarwal and Sachar, 2016).

It is evident that schools where international education is practised are centres of cultural pluralism and multiculturalism. This is could be due to the diversity of nationalities attending the schools or 
because of the synthesis of a 'third culture' from the collision between expatriate and host country cultures (Useem, 1976; Langford, 1998). By extension schools in different countries that share a common international curriculum will most likely share common values. As such teachers and students from such schools who are offering international education may have plural national origins, which they express and celebrate in terms of national costumes, food and festivals but they may also show convergence in their educational values. Mattern (1991, p. 214) describes this as 'the mix-and-stir approach to international education'. In the memorable phrase of Zaw (1996, p. 128), multiculturalism in education can be 'a substantial mono-culturalism as to values, mitigated by tolerance of exotic detail'. In other words, there are aspects of practice of international education that may be de-emphasised by the global diffusion of quality standards but enhanced and celebrated in other areas of practice (Cambridge, 2003). The problem may be that international education promotes and celebrates cultural diversity only in its exotic and peripheral 'saris, samosas and steel bands' components (Pasternak, 1998, p. 260). This is idea that apparently has a wider currency because, in the context of international business, Klein (2000, p. 117) describes the tendency of global branding of commodities to promote cultural homogeneity as 'mono-multi-culturalism'. Global cultural convergence towards the values of the 'transnational capitalist class' is the outcome of globalist international education. Participants in international education may show cultural convergence either as members of that class or as its servants. Cambridge (1998) argues that the staff recruitment policies of an international school may be expected to reinforce convergence between the values of the teachers and its normative organizational culture.

Give a comparative analysis of education in USA and japan with respect to the constitutional provision, administration, finance and educational structure

\section{Introduction}

Education is the foundation of society, and since Japanese and American societies are different in many ways, it may not be surprising that aspects of the two countries' educational systems are different, though not excluding certain commonalities. While the need to turn out knowledgeable and adaptable workers is common to all industrialized nations, the problems inherent in doing this vary widely because of different cultural conditions. In the case of Japan and the United States, they are almost opposite due to cultural and philosophical reasons.

Japan is not only a homogeneous culture - ethnically, socially, economically and in most other ways -but one where conformity is a social ideal. Japanese individuals take their identity from the family, school, club, corporation or other group to which they belong. Japan is a relatively small country with slightly more than half the population of the United States. The size of japan is about the size of California and with no natural resources. Even before the late 19th century, when Japan was thrust into contact with the West, the Japanese understood that if they were to prosper they would do so by their wits. Since education also became the means by which the best jobs and other benefits were distributed, educational achievement became an individual as well as a national priority. The Japanese also agree on the nature of education. The goal is simply to convey knowledge from the teacher to the student, a concept of education that readily lends itself to measurement by standardized tests. It is not to promote a child-oriented purpose such as discovering and developing the skills an individual child might possess. The result is an efficient, centralized, even authoritarian network of primary and high schools that brings most students to an enormously high level of achievement. "

The United States, by contrast, is a heterogeneous nation that makes an ideal out of individualism. Unlike Japan, America has, at least until recently thrive on the basis of vast natural resources, whist valuing education. There are some remarkable achievements in America with regards to education. The quality and diversity of this country's more than 3,000 institutions of higher education are the envy of the world.

There is debate in American by political and educational leaders about the education of the ethnic minorities because the state cannot afford not to educate this so-called "high risk" students, especially those from disadvantage backgrounds and who have never been particularly well served by the American public schools. The education of this class of people is for obvious social and economic reasons. Japanese leaders on the other hand are yet to understand through research, the faith of the 
young people who do not succeed under their rigid examination system. Unlike that of the United States, the Japanese system does not offer second chances for late bloomers or others who do not perform.

\section{Comparative analysis of education in USA and japan with respect to the administration, and educational structure}

Lager percent of American schools does not require uniforms but $20 \%$ does, whilst in japan the students suit up from junior high school on. The traditional uniform is a high-collared, black, militarystyle suit for boys and a beribboned sailor blouse and pleated skirt for girls (sorry ladies, there's no pants option). Japanese secondary schools discourages makeup, nail polish, hairstyles, and even eyebrow grooming by placing a strict ban on these. Japanese schools do not distinguish senior from junior with regard to work in the school, rather both students and teachers roll up their sleeves and spend a few minutes every day clean the floors, and even scrub the toilets. This inculcate discipline into the students and discourages them from such practices as putting gum under their chair or doodling on the desks, because they know they will just have to clean it up themselves. This is not the case in American schools. It is stated that it will be a night mare to leaving 30 teenagers unsupervised in a classroom. In America a teacher can call in sick and a substituted teacher takes responsibility, however, Japanese secondary schools rarely use substitutes; instead, students are trusted to study quietly and independently. Greetings as cultural norm are an integral part of Japanese culture, and this is extended to schools. At the beginning and end of each class, students stand, then bow in unison and greet the teacher. Japanese students do get a five weeks summer holiday (just about half as long as America's get). The Japanese summer break is always in the middle of the school year, and though school is technically out, both students and teachers come to school almost every day for club activities. Even elementary school students are assigned a legendarily hefty summer homework packet.

During the occupation of Japan by American after World War II, the Japanese adopted the American 6-3-3 model, however, the elementary and secondary education is much more centralized than in the United States. Generally, Kindergartens are private in Japan. Elementary school is grades $1-6$. Middle School is for grades $7-9$, and grades 10-12 attend high school. Education is compulsory through the ninth grade (Cooke, 2005). The structure of education system in Japan therefore, includes preschool, primary, lower secondary, higher secondary and college/university.

Many American public high schools are comprehensive. While there are a few comprehensive high schools in Japan, they are not popular. In the United States, the choice of secondary schools by student is either based on school district assignment or on personal choice whilst in Japan, examination performance is used to admit an overwhelming majority of students to both high schools and university programs (Cooke, 2005). Admission to all levels of education requires passing of the entrance exams. The most essential tests are those given for entrance to the higher secondary schools and the universities. Both private and public high schools in Japan apply such tests usually in the main five fields: Japanese, English, Mathematics, Science and Social Studies.

\section{Comparative analysis of education in USA and japan with respect to constitutional provision}

Japan's former constitution, the Constitution of the Empire of Japan of 1889, did not have a provision on the right to education, despite the debate that ensued on the issue when the laws were being enacted. The Meiji government determined that the fundamental principle on education should be provided by the Education Rescript of 1890, not by the Constitution. A new education system was established under the Rescript. The current Constitution of Japan of 1946 contains the following provision on the right to education: Article 26. All people shall have the right to receive an equal education correspondent to their ability, as provided by law. It shall be obligatory for all citizens to have all boys and girls under their protection receive ordinary education as prescribed by law. Such compulsory education shall be free. In accordance with the spirit of the Constitution, the Basic Act on Education sets forth in more details than the aims and principles of education. As per the Constitution and the Basic Act on Education, the School Education Act prescribed that compulsory education is for nine years. In order to guarantee the opportunity for such compulsory education and ensure adequate standards, the Basic Act on Education states that the national and local governments are responsible for implementing 
compulsory education through appropriate role sharing and mutual cooperation. According to the laws no tuition fees are charged for compulsory education in schools established by the national and local governments. In addition, the Basic Act on Education obligates the national and local governments to take measures to provide financial assistance to those who, in spite of their abilities, encounter difficulties in receiving education for economic reasons. People with disabilities are protected by the national and local governments and are to receive adequate education in accordance with their level of disability.

The United States operates a highly decentralized system of education. The state generally, has the authority to create and administer public schools. The right to education is not explicitly stated in the federal constitution. This deficiency in the Constitution, has resulted in the state governments being in control of the right to education under the guidance of the Tenth Amendment.2

The amount of education and right to that education for the citizenry are the responsibilities of the state and local authorities in the United States (Peter, 1997).

There is no elaborate federal school system nor is there a national framework or laws that prescribe curricula or control most other aspects of education. The federal government, although playing an important role in education, does not establish or license schools or govern educational institutions at any level. The No Child Left behind Act of 2001 (No Child Left Behind) is a landmark in education reform designed to improve student achievement and change the culture of U.S. schools. The law was passed by Congress with overwhelming bipartisan support and signed into law by President George W. Bush on January 8, 2002. No Child Left Behind reauthorized the Elementary and Secondary Education Act (ESEA) - the principal federal law affecting education from kindergarten through high school. In amending ESEA, the new law represents a sweeping overhaul of federal efforts to support elementary and secondary education in the United States. In exchange for federal aid for education, states must establish systems of accountability that ensure that funds are used to improve the quality of education offered to every child in the state.

\section{References}

[1].Altbach, P. G. and Knight, J. (2007) 'Journal of Studies in International Education the Internationalization of Higher Education: Motivations and Realities', Journal of Studies in International Education, 11(290). doi: $10.1177 / 1028315307303542$.

[2].Azeutziu, (2014). Modernization vs Globalization, tulaneict4d.wordpress.com/2014/02/07/modernizationglobalization access: 01-10-2017, 16:24.

[3].Cambridge, J., Thompson, J., Cambridge, J. and Thompson, J. (2010) 'Compare : A Journal of Comparative Internationalism and globalization as contexts for international education Internationalism and globalization as contexts for international education', Journal of Comparative and International Education, 13(37), pp. 37-41. doi: $10.1080 / 0305792042000213994$.

[4].Mccabe, L. T. (2001) 'Internationalization : The Impact on Education Abroad Programs', 5(2), pp. 138-145. [5].Phillips, D., Schweisfurth, M. (2014). Comparative and International Education: An Introduction to Theory, Method.

[6].Vandana Aggarwal, V., and Sachar, G (2016). An insight into the role of education for social change and modernization. International Education and Research Journal Vol 2, No 9 (2016). 